Int. J. Electrochem. Sci., 14 (2019) 9948 - 9959

International Journal of

ELECTROCHEMICAL

SCIENCE

$\underline{\text { www.electrochemsci.org }}$

\title{
Investigation of Influence of Microstructure on FH32 Steel Corrosion Properties using Gleeble Simulation of Heat-Affected Zone and Electrochemical Methods
}

\author{
Zuo-peng Zhao ${ }^{1}$, Peng-fei Xu ${ }^{1,}{ }^{*}$, Hong-xia Cheng ${ }^{1}$, Xiang-yu Lu ${ }^{1}$, Jili Miao ${ }^{2}$, Yunsai Chen ${ }^{3}$, \\ Lei Yang ${ }^{3}$ \\ ${ }^{1}$ College of Harbor Coastal and Offshore Engineering, Hohai University, Nanjing 210098, China \\ 2 Jiangnan Shipyard (Group) Co. LTD., Shanghai 201913, China \\ ${ }^{3}$ National Deep Sea Center, Qingdao 266237, China. \\ *E-mail: xupengfei@hhu.edu.cn
}

doi: $10.20964 / 2019.10 .50$

Received: 15 June 2019 / Accepted: 30 July 2019 / Published: 30 August 2019

The corrosion behavior was investigated for each heat-affected zone (HAZ) comprising a FH32 steel immersed in $3.5 \% \mathrm{NaCl}$ solutions. To research the corrosion behavior of each HAZ sub-region, HAZ thermo-mechanical simulations were performed prior to the electrochemical tests. The results revealed that the corrosion resistance of the fine-grained HAZ (FGHAZ) comprising the steel is superior to that of other HAZ sub-regions. Moreover, the coarse-grained HAZ (CGHAZ) exhibited the worst corrosion resistance of the weld joint. The changes in the corrosion resistance of the HAZ sub-regions were attributed to variations in the microstructural sensitivity to corrosion behavior. Furthermore, the results indicated that the number, size, and distribution of martensite/austenite (M/A) constituents, as well as the grain size of the relevant phase can affect the resistance.

Keywords: C-Mn steel; heat-affected zone; EIS; microstructure; corrosion behavior

\section{FULL TEXT}

(C) 2019 The Authors. Published by ESG (www.electrochemsci.org). This article is an open access article distributed under the terms and conditions of the Creative Commons Attribution license (http://creativecommons.org/licenses/by/4.0/). 